University of Zurich

Department of Economics

Working Paper Series

ISSN 1664-7041 (print)

ISSN1664-705X(online)

Working Paper No. 9

\title{
Inequality Perceptions, Distributional Norms, and Redistributive Preferences in East and West Germany
}

Andreas Kuhn

March 2011 


\title{
Inequality Perceptions, Distributional Norms, and Redistributive Preferences in East and West Germany
}

\author{
Andreas Kuhn, University of Zurich and IZA*
}

March 2011

\begin{abstract}
This paper studies differences in inequality perceptions, distributional norms, and redistributive preferences between East and West Germany. As expected, there are substantial differences with respect to all three of these measures. Surprisingly, however, differences in distributional norms are much smaller than differences with respect to inequality perceptions or redistributive preferences. Nonetheless, individuals from East Germany tend to be more supportive of state redistribution and progressive taxation, and less likely to have a conservative political orientation, even conditional on having the same inequality perceptions and distributional norms.
\end{abstract}

JEL classification: D31, D63, H50, J31

Keywords: subjective inequality indices, redistributive preferences, political preferences

${ }^{*}$ I thank Simon Büchi and Andreas Steinhauer for superb research assistance. Financial support by the Austrian Science Fund ("The Austrian Center for Labor Economics and the Analysis of the Welfare State") is gratefully acknowledged.

Contact: Andreas Kuhn, University of Zurich, Department of Economics, Mühlebachstrasse 86, 8008 Zurich, Switzerland; andreas.kuhn@econ.uzh.ch. 


\section{Introduction}

It is well documented that individuals from different countries differ widely in their support for redistribution (e.g. Alesina and Glaeser, 2004). One important question within this context is whether institutions that favor redistribution, once established, have any feedback on individuals' distributional norms or their preferences for redistribution. Against this background, the unique event of the German reunification has attracted considerable attention because it provides an opportunity to shed light on the role different political and economic institutions play in influencing individuals' preferences. Assuming that the separation of Germany was orthogonal to such preferences (see Alesina and Fuchs-Schündeln, 2007, on this issue), the comparison between East and West Germany may indeed be informative about the feedback from institutions on individuals' preferences in East and West Germans.

Indeed, several recent empirical studies show that there are substantial differences in redistributive preferences, as well as other preferences and attitudes, between East and West Germany. Both Corneo (2004) and Alesina and Fuchs-Schündeln (2007) show that East Germans are substantially more likely to support redistribution by the state than West Germans, even a full decade after German reunification. Rainer and Siedler (2008) report a difference in the subjective evaluation of fair marginal tax rates for people working in different occupations between East and West Germans. Interestingly, they only find a difference in the evaluation of the marginal tax rate for an unskilled worker, but not with respect to the tax rate for a manager. In an experimental study, Ockenfels and Weimann (1999) find that East Germans show significantly less cooperation and solidarity than West Germans. In a related study, Rainer and Siedler (2009) show that there is also a substantial difference in social distrust between the East and West Germany and that, specifically, East Germans have less overall social trust and less trust in specific institutions, such as the legal system or the parliament, than West Germans. Consistent with this finding, Heineck and Süssmuth (2010) report large differences in general trust between East and West Germans. Moreover, they find that East Germans are less likely to see others as fair or as helpful. The underlying explanation in all these studies is that individuals from East Germany lived under a socialist regime, many of them for several decades. Taken together, these studies therefore support the view that institutions have an impact on individual preferences and attitudes. 
This paper adds to this small but growing literature, focusing on three unique measures of individuals' inequality perceptions, distributional norms regarding the legitimate level of wage inequality, and redistributive preferences that are conceptualized simply as the discrepancy between the former two measures. As expected, I find that there are substantial differences between East and West Germany regarding all three of these measures. For example, I find that East Germans have, on average, a larger demand for redistribution than West Germans. The overall findings presented in this paper are by and large in line with previous evidence, but there are also some new and surprising conclusions. Probably the most interesting, and also most surprising, result is that individuals from East and West Germany differ much less in their evaluation of how the ethical distribution of wages should look like than in their perceptions of actually existing wage differentials. This finding likely reflects the fact that there have been substantial changes in the East German wage structure since the German reunification. ${ }^{1}$

The empirical analysis further shows that there are large differences in individuals' more general political preferences between East and West Germans, even conditional on having the same inequality perceptions and distributional norms. Nonetheless, differences in inequality perceptions and distributional norms explain a substantial part of the raw differences in political preferences. Specifically, East Germans are much more likely to believe that is the government's responsibility to reduce existing inequalities that are judged as being too large. Thus while there are only small differences in distributional norms (regarding ethically acceptable pay differentials across people working in different occupations), and while differences in redistributive preferences are therefore mainly driven by differences in inequality perceptions, it is nonetheless true that East Germans are much more likely than West Germans to think that it is the state's responsibility to reduce existing inequalities. Interestingly, it thus appears that communism shaped individuals' perception of the role of the state regarding wage inequality judged to be unethical, but did not substantially affect individuals' beliefs of what they view as an ethical or legitimate distribution of wages across different occupations.

The remainder of this paper proceeds as follows. In the next section, I discuss the data source and the key measures used in the empirical analysis. The empirical analysis is then

\footnotetext{
${ }^{1}$ Several empirical studies show that wage inequality has increased substantially in East Germany since reunification (e.g. Biewen, 2000; Franz and Steiner, 2000). Moreover, Fuchs-Schündeln et al. (2010) show that there have been similar trends in increasing inequality in both disposable household income and consumption as well.
} 
presented and discussed in the subsequent two sections. Differences in subjective inequality measures and redistributive preferences between East and West Germany are presented and discussed in section 3 , while section 4 presents evidence on the relation between these measures and individuals' more general political preferences. Finally, section 5 concludes.

\section{Data and Measures}

I use data from three surveys of the International Social Survey Program (ISSP), all three of which focus closely on issues of social inequality. The surveys were administered in 1987, 1992, and 1999, respectively. However, data for East Germany are only available for 1992 and 1999. All three surveys contain an interesting series of questions on respondents' subjective estimates of both actual and ethical earnings for people working in different occupations. ${ }^{2}$ These estimates reflect pay differentials across occupations that respondents perceive to exist and pay differentials across occupations that they view as legitimate, respectively.

Figure 1

Figure 1 shows simple averages of individuals' estimates of actual and ethical wages for people working in different occupations, separately for respondents from East and West Germany. Several features are noteworthy. First note that the ranking of occupations with respect to actual wages is almost the same in East and West Germany, and that the ranking only differs at the very top of the distribution. Second, actual wages estimates of East Germans for most occupations are lower than those of West Germans. For example, the actual wage estimate for a skilled factory worker (a lawyer) averages $€ 1,354(€ 4,852)$ among East Germans and $€ 1,834$ $(€ 6,398)$ among West Germans (averages are calculated using data from only 1992 and 1999). Interestingly, the only exceptions where this pattern does not apply are the wages of a federal judge and of a minister of the national cabinet. ${ }^{3}$ Similarly, average ethical wage estimates also differ between respondents from the two parts of the country. The average ethical wage for

\footnotetext{
${ }^{2}$ Specifically, respondents were asked the following two questions (original wording from the source questionnaire of the ISSP): (1) "We would like to know what you think people in these jobs actually earn. Please write how much you think they actually earn each month before taxes. Many people are not exactly sure about this, but your best guess will be close enough." (2) "Next, what do you think people in these jobs ought to be paid. How much do you think they should earn each month before taxes, regardless of what they actually earn."

${ }^{3}$ This finding is consistent with Rainer and Siedler (2009), who show that East Germans have less trust in both the constitutional court and in the parliament than West Germans.
} 
a skilled factory worker (lawyer) equals $€ 1,817(€ 3,944)$ among East Germans and $€ 2,136$ $(€ 5,148)$ among West Germans. Third, there are substantial differences in both East and West Germany between actual and ethical wage estimates for most occupations. More specifically, ethical wages are higher (lower) than actual wages for the lower (higher) paid occupations, resulting in less spread of ethical than of actual wages across the same set of occupations. This finding implies that the average respondent in both East and West Germany would prefer a more equal distribution of wages across different occupations than what she actually perceives to exist.

This statement can be made much more precisely. In fact, it is possible to construct two different subjective inequality indices and a measure of redistributive preferences using these individual estimates of actual and ethical wages (see Kuhn, 2009, for details), and the empirical analysis presented below will mainly focus on these three measures. Specifically, it is possible to construct two distinct subjective Gini coefficients analogous to the conventional Gini coefficient used to describe objective inequality. ${ }^{4}$ The first of these two Gini coefficients describes individuals' perceptions of the actual level of inequality $G(i)^{\text {actual }}$, while the second refers to people's ethical level of inequality $G(i)^{\text {ethical }}$ and thus reflects an individual's distributional norms. Note that there is variation in these two inequality indices across individuals, in contrast to objective measures of inequality, as long as individuals have different perceptions of actual wages and/or different evaluations of ethical wages (as I will show below, people indeed have widely different inequality perceptions and normative beliefs). The third measure is simply the relative difference between the two inequality indices, $R(i)=1-\left(G(i)^{\text {ethical }} / G(i)^{\text {actual }}\right)$. This measure describes individuals' demand for equalization of market wages (i.e. $R(i)=0$ if actual wage inequality is exactly the same as the evaluation of ethical wage inequality). Alternatively, one may also think of $R(i)$ as measuring the absence of market justice because higher values of $R(i)$ imply a larger discrepancy between an individual's ethical and actual level of inequality of market wages. ${ }^{5}$ Thus $R(i)=0$ indicates that an individual perceives the market distribution of wage to be perfectly just, in the sense that there is no discrepancy between his

\footnotetext{
${ }^{4} \mathrm{As}$ in the case of objective wage data, a coefficient of 0 denotes absolute equality while a coefficient of 1 denotes the maximum level of inequality. In my application, a coefficient of 0 would imply that wage estimates by the individual under consideration are equal for all occupations. A coefficient of 1 is unlikely to be observed, but a coefficient close to 1 would imply that an individual estimates the earnings of one occupation to be much higher than the earnings in all other occupations.

${ }^{5}$ Appendix table A.1 shows selected descriptive statistics for these three measures.
} 
or her perception of the distribution of market wages and his or her desired distribution of market wages.

\section{$3 \quad$ Subjective Inequality Indices and Redistributive Preferences}

\subsection{Graphical Evidence}

I start the empirical analysis with a simple graphical description of the distribution of subjective inequality measures and redistributive preferences in East and West Germany. Figure 2 shows simple density estimates for the three measures discussed before, first by region only (figures at the top) and then by both region and year of survey (figures at the bottom). First note that the perceived level of wage inequality is considerably larger than the ethical level of wage inequality on average for both East and West Germany. Panels (a) and (b) show that the distribution of actual wages is clearly skewed to the right, while the distribution of ethical wage estimates has almost no skew. From this, it immediately follows that most individuals have a positive demand for redistribution. Indeed, an overwhelming majority of individuals in both East and West Germany would prefer more equal market wages across different occupations, relative to the wage differentials they perceive to actually exist; see panel (c). ${ }^{6}$

\section{Figure 2}

Aside from these similarities, there are also notable differences between East and West Germany. First, panel (a) of figure 2 shows that there is a remarkable difference in the overall distribution of inequality perceptions between East and West Germans. As expected (see footnote 1), inequality perceptions are substantially higher among East Germans. There is a difference in the distribution of the ethical level of wage inequality as well, as evident from panel (b), but the difference regarding distributional norms appears to be much smaller than the difference regarding perceived wage inequality. ${ }^{7}$ Somewhat surprisingly, however, the ethical level of wage inequality even appears to be slightly higher among East than West Germans. Panel (c) shows the distribution of redistributive preferences. Clearly, the different distributions support the view that East Germans favor more redistribution than West Germans.

\footnotetext{
${ }^{6}$ More specifically, appendix table A.1 shows that 95.7\% (92.3\%) of all individuals from East (West) Germany have a strictly positive demand for redistribution.

${ }^{7}$ This finding is consistent with corresponding descriptive statistics reported in appendix table A.1, as well as with the results from the regression analysis discussed below (see section 3.2).
} 
Taken together, the figures also suggest that this difference in redistributive preferences is mainly driven by differences in perceptions of the actual level of inequality, and not so much by differences in distributional norms.

The lower panel of figure 2 shows how the distribution of these three measures changed over time, for East and West Germans separately. Interestingly, panel (d) shows that the distribution of individual estimates of actual wage inequality increased over time in West Germany, while it slightly decreased in East Germany. There is thus some convergence in inequality perceptions over time between the two parts of the country. In contrast, panel (e) shows that the distribution of ethical inequality in the two regions moved in the same direction over time. There is a substantial upward shift in the distribution of ethical inequality in both East and West Germany, i.e. people have become more tolerant towards wage inequality. In fact, this upward shift in the distribution of ethical wage inequality was so large that the distribution of redistributive preferences shifted slightly downwards over time, the upward shift in inequality perceptions notwithstanding, as shown in panel (f).

\subsection{Regression Estimates}

To further elaborate on these differences in subjective inequality measures between East and West Germans, I run a series of simple regression models that take the following basic form:

$$
y_{i t}=\beta_{0}+\text { East }_{i t} \alpha+x_{i t} \beta+\lambda_{t}+\varepsilon_{i t},
$$

with $y_{i t}$ denoting either one of the two subjective inequality indices (i.e. inequality perceptions or distributional norms) or the measure of redistributive preferences of individual $i$ in year $t .8$ The regressor of main interest is East $i t$, a dummy variable denoting current residency in East Germany. ${ }^{9}$ The regression also includes a series of control variables and survey-year fixed effects, denoted by $x_{i t}$ and $\lambda_{t}$, respectively. ${ }^{10}$ Moreover, I show for each outcome both

\footnotetext{
${ }^{8}$ The regressions include observations from the 1987 survey (West Germany only) as well.

${ }^{9}$ The ISSP only records current residency, but not place of birth, and selective migration from one part to the other part of Germany is thus a potential concern. I do not believe, however, that migration can fully explain the results presented later on. See Alesina and Fuchs-Schündeln (2007) on the issue of migration from East to West Germany, and vice versa, before 1989.

${ }^{10}$ The full list of control variables is as follows: Personal income (rank), social mobility index, the perception that ascribed (acquired) characteristics are important in determining one's pay, the belief that needs (effort) should be important in determining one's pay, the perception of conflicts in society, a cubic in age, education (in years), a female dummy, labor market status (3 categories), and occupation (10 categories).
} 
the raw difference between East and West Germans as well as the remaining difference once I include the full set of control variables. I also show the estimated time effects, allowing me to quantify the distributional shifts between the different survey years that are evident from figure 2. Finally, I also include interactions between the dummy for East Germany and the year dummies, thereby allowing for the possibility that the difference between East and West Germany in the considered outcomes varies over time. Table 1 shows the resulting estimates.

Table 1

The first three columns show results regarding individuals' inequality perceptions. The raw difference between East and West Germans is about 0.07 Gini points. In relative terms, inequality perception is thus about $16 \%$ higher in East than in West Germany. The inclusion of the control variables has only a marginal impact on the corresponding parameter estimate, and a large and significant difference of 0.067 Gini points after including the full set of control variables remains (in relative terms, the remaining difference equals about 15\%). Consistent with the corresponding pattern from figure 2 , the regression results show that there are significant time effects as well. ${ }^{11}$ The third column also includes the interaction terms between the East German dummy and the dummies indicating year of survey. Estimates from this model show that the difference in inequality perceptions between East and West Germany has narrowed considerably over time, from 0.082 Gini points in 1992 to only 0.036 Gini points in 1999.

The next three columns show regression results regarding the ethical level of wage inequality (i.e. distributional norms). Surprisingly, and in contrast to inequality perceptions, the ethical level of wage inequality is somewhat higher among East than West Germans, i.e. East Germans are slightly more tolerant towards wage inequality than West Germans. ${ }^{12}$ The resulting point estimate for the East dummy is 0.014 in both specifications. Thus there is a much smaller, though still significant, difference in social norms than in inequality perceptions between East and West Germany. ${ }^{13}$ In line with the graphical evidence presented above, the

\footnotetext{
${ }^{11}$ Note that there are no observations for East Germany for the year 1987. The estimated effect on the dummy for the year 1992 thus only refers to changes in West Germany, while the estimated effect on the dummy for the year 1999 refers to changes for both East and West Germany.

${ }^{12}$ In line with this finding, East Germans are somewhat more likely to think that "working hard" and "doing one's job well" should be important in determining pay.

${ }^{13}$ This holds true if one takes the fact into account that the mean ethical inequality is considerably smaller than the average perceived inequality (see appendix table A.1).
} 
regression estimates show that distributional norms changed even more over time than inequality perceptions. Most notably, the increase in the ethical level of wage inequality between 1992 and 1999 is about three times as large as the corresponding increase from 1987 to 1992. The third model again includes interaction terms between year of survey and the dummy for East Germany. These estimates show that the difference in the ethical level of wage inequality between East and West Germany switched from positive in 1992 (0.031) to negative in 1999 $(-0.022)$.

The last three columns show analogous results for redistributive preferences. In this case, the inclusion of individual level controls appears to have some, but still limited, influence on the estimated difference between East and West Germany. The raw difference amounts to 0.059, which shrinks to 0.052 if the full set of control variables is included. This finding is again in line with previous evidence showing that East Germans have a higher demand for redistribution than West Germans. Furthermore, while there is virtually no change in average redistributive preferences from 1987 to 1992, there is a substantial and significant decrease from 1992 to $1999 .{ }^{14}$ The above results make it clear that this finding is the consequence of a disproportional increase in the ethical level of wage inequality because inequality perceptions had increased as well within this period. The final column shows that the difference in the demand for redistribution between East and West Germany increased considerably over time, from 0.037 in 1992 to 0.083 in 1999, reflecting the underlying time trends in the difference in inequality perceptions and distributional norms, respectively.

\subsection{Differences Across Birth Cohorts}

Alesina and Fuchs-Schündeln (2007) argue that living under a socialist regime for up to 45 years had a long lasting impact on individuals' attitudes, especially on their attitudes towards the role of the state. More specifically, they find that convergence of attitudes towards the state proceeds very slowly and that it will take up to two generations before attitudes of East and West Germans will fully converge. Looking at differences across birth cohorts may therefore yield additional insights, and thus figure 3 shows differences in inequality perceptions, distributional norms, and redistributive preferences by birth cohort and separately for respondents

\footnotetext{
${ }^{14}$ Again note that, since there are no observations from East Germany in 1987, the observation that preferences did not change from 1987 to 1992 relates to West Germany only.
} 
from East and West Germany, respectively, for all individuals born in 1910 or later (there are too few observations from individuals born before 1910, and they are thus left out).

Figure 3

First, panel (a) of figure 3 shows how inequality perceptions differ between East and West Germans by year of birth. There is clearly a substantial difference in inequality perception between East and West Germans for every birth cohort, the difference appears to be of the same size for most cohorts, but possibly showing a slight trend towards narrower differences for younger cohorts. Panel (b) again shows the surprising result that East Germans tend to have a higher level of ethical inequality than West Germans, and that differences tend to be much smaller than differences in perceptions. The difference in distributional norms varies somewhat across birth cohorts, and is largest among the oldest and youngest cohorts and smallest for the cohorts born between about 1935 and 1960. Finally, panel (c) shows that differences in redistributive preferences are larger, again because they reflect differences in both inequality perceptions and distributional norms. Driven mainly by underlying differences in inequality perceptions, there is a positive difference in redistributive preferences between East and West Germans for every birth cohort, but the difference appears to narrow slightly for younger cohorts (similar to the trend in inequality perceptions).

Overall, I find that differences in inequality perceptions are smaller for younger birth cohorts. It is much more remarkable, however, that there are almost no differences in distributional norms for any of the birth cohorts considered in the analysis, except perhaps for the youngest cohorts (for these cohorts, however, the ethical level of wage inequality is even slightly higher among East Germans). As a consequence, differences in redistributive preferences are indeed somewhat smaller among younger birth cohorts, in line with the corresponding finding by Alesina and Fuchs-Schündeln (2007) that there is slow convergence in redistributive preferences between East and West Germany.

\section{Political Preferences}

The second part of the empirical analysis studies how the two subjective inequality measures and redistributive preferences, respectively, are associated with individuals' political preferences, such as their support for intervention by the government regarding wage differentials 
that are viewed as illegitimate. To do so, I estimate the parameters of a regression model that takes the following form:

$$
\omega_{i t}=\beta_{0}+\text { East }_{i t} \alpha+y_{i t} \gamma+x_{i t} \beta+\lambda_{t}+\varepsilon_{i t},
$$

where $\omega_{i t}$ describes the political preferences of individual $i$ in year $t$ : their support for redistribution by the state, their support for progressive taxation, and their identification with conservative politics (more information on these measures is given below). The key regressor in all three cases is $y_{i t}$, which denotes the inclusion of either the measure of redistributive preferences or the two subjective inequality indices (i.e. both inequality indices at the same time). I also show results excluding $y_{i t}$ to illustrate the quantitative impact of $y_{i t}$ on the size of parameter $\alpha$. Parameter estimates are shown in table 2 .

\section{Table 2}

The first three columns show results for individuals' support for redistribution by the state. ${ }^{15}$ The difference between East and West Germans is large and highly significant in all three specifications. The point estimate in the first specification is 0.587 (with a small standard error of 0.034 ). This implies a relative difference of about $16 \%$ between East and West Germans in their general support for redistribution by the state. The next two specifications show that the inclusion of $y_{i t}$ has a substantial impact on this difference. First, including redistributive preferences decreases the difference to 0.537 , which remains a large and significant difference. The third column includes both inequality indices (instead of redistributive preferences). This decreases the remaining difference even more, to 0.505. Redistributive preferences can thus explain about $8.5 \%(=100 \%[1-(.537 / .587)])$, while inequality perceptions and distributional norms can explain about $14 \%(=100 \%[1-(.505 / .587)])$ of the remaining difference in the support for redistribution by the state. However, even in the last specification, the difference between East and West Germans remains both statistically and quantitatively significant (the difference is equal to about half a standard deviation of the dependent variable).

\footnotetext{
${ }^{15}$ This variable measures individuals' agreement with the following statement: "It is the responsibility of the government to reduce the differences in income between people with high incomes and those with low incomes." The corresponding variable ranges from 1 to 5 , with 5 denoting perfect agreement with the statement.
} 
The next three columns show estimates for individuals' support for progressive taxation, similar to the questions on marginal tax rates used in Rainer and Siedler (2009). ${ }^{16}$ As in the case of people's general support for redistribution by the state, there is a substantial difference between East and West Germans. Even though this difference shrinks once controls for redistributive preferences or inequality perceptions and distributional norms are included, a significant and large (equal to about one fifth of a standard deviation of the dependent variable) difference in individuals' support for progressive taxation with the same distributional preferences remains. As before, redistributive preferences as well as inequality perceptions and distributional norms explain a substantial fraction of the observed East-West difference in the support for progressive taxation that remains after conditioning on the full set of controls (about $13 \%$ and $27 \%$, respectively). Also note that the estimated difference in the support for progressive taxation is smaller, in relative terms, than the corresponding difference in the support for redistribution by the state.

The remaining three columns report results for individuals' political orientation on a simple left-right scale, with higher values indicating a more conservative orientation. ${ }^{17}$ East Germans are much less likely to state that they have a conservative (or, say, right-wing) political orientation than West Germans. Again, this difference remains large and significant even if redistributive preferences or subjective inequality indices are explicitly held constant. The remaining difference equals about one third of a standard deviation of the dependent variable. The results imply that the fraction of the East-West difference in individuals' political orientation that can be explained by differences in redistributive preferences or inequality perceptions and distributional norms is about $8 \%$ and $9 \%$, respectively.

\section{Figure 4}

Finally, figure 4 shows average political preferences for East and West Germans and by birth cohort. Panel (a) shows a large difference in the support for redistribution by the state for each cohort. Moreover, there is a clear tendency towards smaller differences for younger cohorts for

\footnotetext{
${ }^{16}$ The variable measures individuals' response to the following question: "Do you think people with high incomes should pay a larger share of their income in taxes than those with low incomes, the same share, or a smaller share?". The corresponding variable takes on values from 1 to 5 , with 1 (5) meaning that respondents think that the share of people with higher incomes should be much smaller (much larger) than the share of people with low incomes.

${ }^{17}$ The variable measures respondents' political orientation on a simple left-right scale running from 1 to 10 , and where the lowest (highest) value denotes the leftmost (rightmost) position.
} 
this outcome. A similar but even more pronounced pattern is visible for individuals' support for progressive taxation, as shown in panel (b). While there is a large difference in the support for progressive taxation for older cohorts, this difference gets smaller and essentially vanishes for younger cohorts. Finally, panel (c) shows differences in individuals' political orientation. Again, differences between East and West Germans are smaller for younger cohorts. Moreover, it appears that most of the observed convergence in attitudes across birth cohorts in this case is driven by corresponding changes among West Germans, i.e. it appears that West Germans have become somewhat less conservative over time.

\section{Discussion}

This paper studies differences in inequality perceptions, distributional norms, and redistributive preferences between East and West Germany using intuitive empirical measures derived from survey data. A first key result of this study is that East Germans demand more redistribution than West Germans, a result in line with previous evidence (e.g. Alesina and FuchsSchündeln, 2007). However, it also shows that differences in inequality perceptions rather than by differences in distributional norms drive this difference in redistributive preferences to a substantial degree. Even more surprisingly, East Germans were slightly more tolerant towards wage inequality than West Germans in 1992 (the sign of the difference in distributional norms changed in the year 1999, however).

This finding is initially somewhat surprising, but note that it is consistent with results reported in an earlier study by Shiller et al. (1991), who found similar attitudes towards income inequality between American and Soviet respondents shortly after the fall of the Berlin Wall. At the same time, the fact that East Germans perceive a much higher level of wage inequality than West Germans likely reflects underlying trends in wage inequality following German reunification in the two parts of the country (i.e. increasing wage inequality in East Germany). Finally, Blanchflower and Freeman (1997) report essentially the same result for the comparison between East and West Germany, even though they find substantial differences in both perceived and ethical wage differentials among a broader group of ex-communist and capitalist countries.

Moreover, I also find large differences in individuals' more general political preferences, and 
especially people's attitudes towards intervention by the state as a means of reducing existing wage inequalities. Specifically, East Germans are much more likely than West Germans to support state intervention with respect to the distribution of incomes and, consistent with this finding, they are also much more likely to support higher taxes for individuals with higher income. Finally, East Germans are substantially less likely to state that they have a conservative political orientation (measured on a simple left-right scale). Interestingly, these differences remain large and statistically significant once redistributive preferences (or its underlying components) are statistically held constant. Nonetheless, differences in inequality perceptions and distributional norms or redistributive preferences, respectively, explain a substantial part of the observed differences in political preferences.

Taken together, the findings presented in this paper suggest that living under a socialist regime did not substantially influence individuals' fundamental distributional norms (i.e. their norms with respect to legitimate wage differentials for people working in different occupations). At the same time, however, it appears that it had a significant impact on people's belief that it is the state's responsibility to intervene if wage differentials are viewed as too large, and it presumably changed individuals' views on the role that the state should more generally play. 


\section{References}

Alesina, A. and Fuchs-Schündeln, N. (2007). Good-bye Lenin (or not?): The effect of communism on people's preferences. American Economic Review, 97(4), 1507-1528.

Alesina, A. and Glaeser, E. (2004). Fighting poverty in the US and Europe: A world of difference. Oxford University Press.

Biewen, M. (2000). Income Inequality in Germany during the 1980s and 1990s. Review of Income and Wealth, 46(1), 1-19.

Blanchflower, D. and Freeman, R. (1997). The attitudinal legacy of communist labor relations. Industrial \& Labor Relations Review, 50(3), 438-459.

Corneo, G. (2004). Wieso Umverteilung? Einsichten aus ökonometrischen Umfrageanalysen. In B. Genser, editor, Finanzpolitik und Umverteilung, pages 55-88. Duncker \& Humblot.

Franz, W. and Steiner, V. (2000). Wages in the East German transition process: Facts and explanations. German Economic Review, 1(3), 241-269.

Fuchs-Schündeln, N., Krueger, D., and Sommer, M. (2010). Inequality trends for Germany in the last two decades: A tale of two countries. Review of Economic Dynamics, 13(1), $103-132$.

Heineck, G. and Süssmuth, B. (2010). A Different Look at Lenin's Legacy: Trust, Risk, Fairness and Cooperativeness in the Two Germanies. IZA Discussion Paper No. 5219.

Kuhn, A. (2009). In the Eye of the Beholder: Subjective Evaluations of Wage Inequality and the Demand for Redistribution. IZA Discussion Paper No. 4360.

Ockenfels, A. and Weimann, J. (1999). Types and patterns: an experimental East-WestGerman comparison of cooperation and solidarity. Journal of Public Economics, 71(2), $275-287$.

Rainer, H. and Siedler, T. (2008). Subjective income and employment expectations and preferences for redistribution. Economics Letters, 99(3), 449-453.

Rainer, H. and Siedler, T. (2009). Does democracy foster trust? Journal of Comparative Economics, 37(2), 251-269.

Shiller, R., Boycko, M., and Korobov, V. (1991). Popular attitudes toward free markets: The Soviet Union and the United States compared. American Economic Review, 81(3), 385-400. 


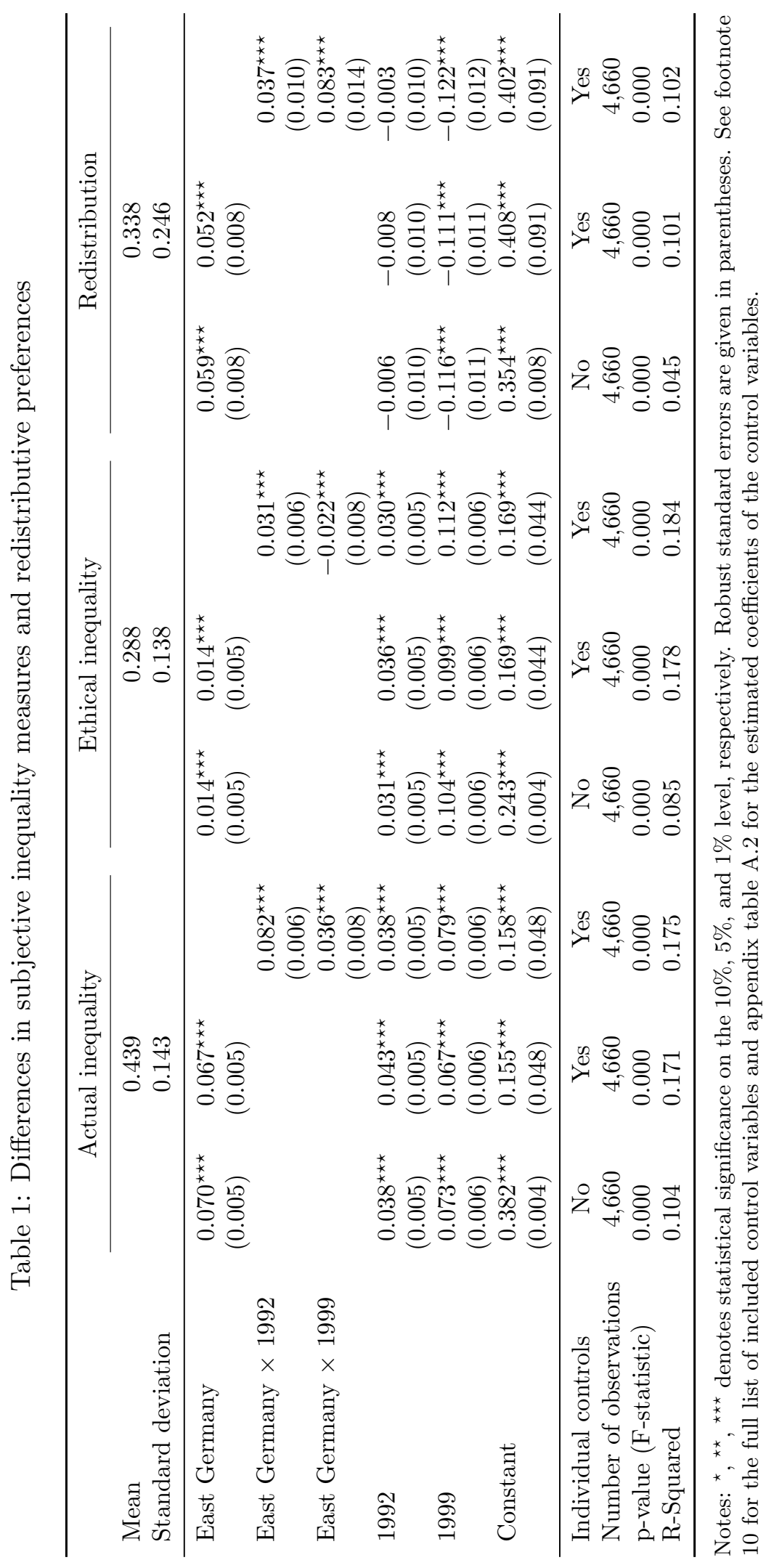




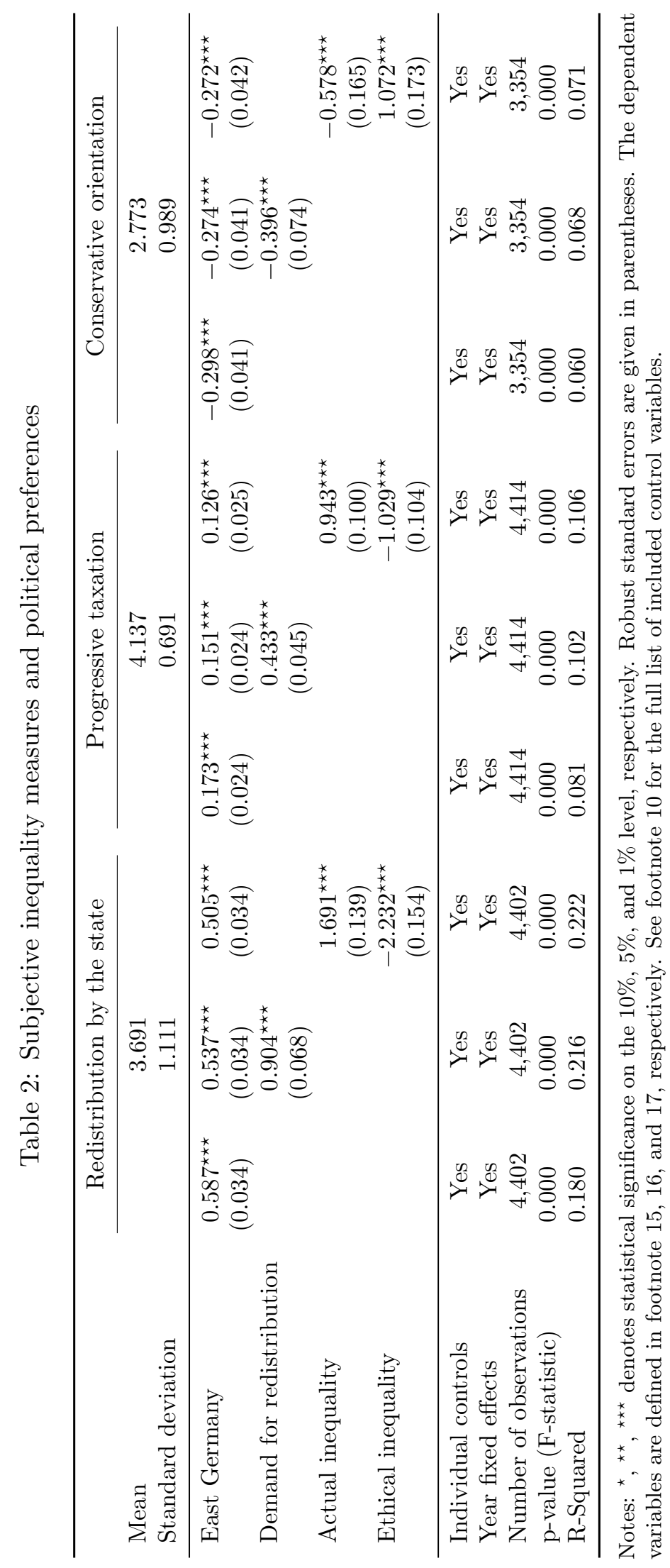




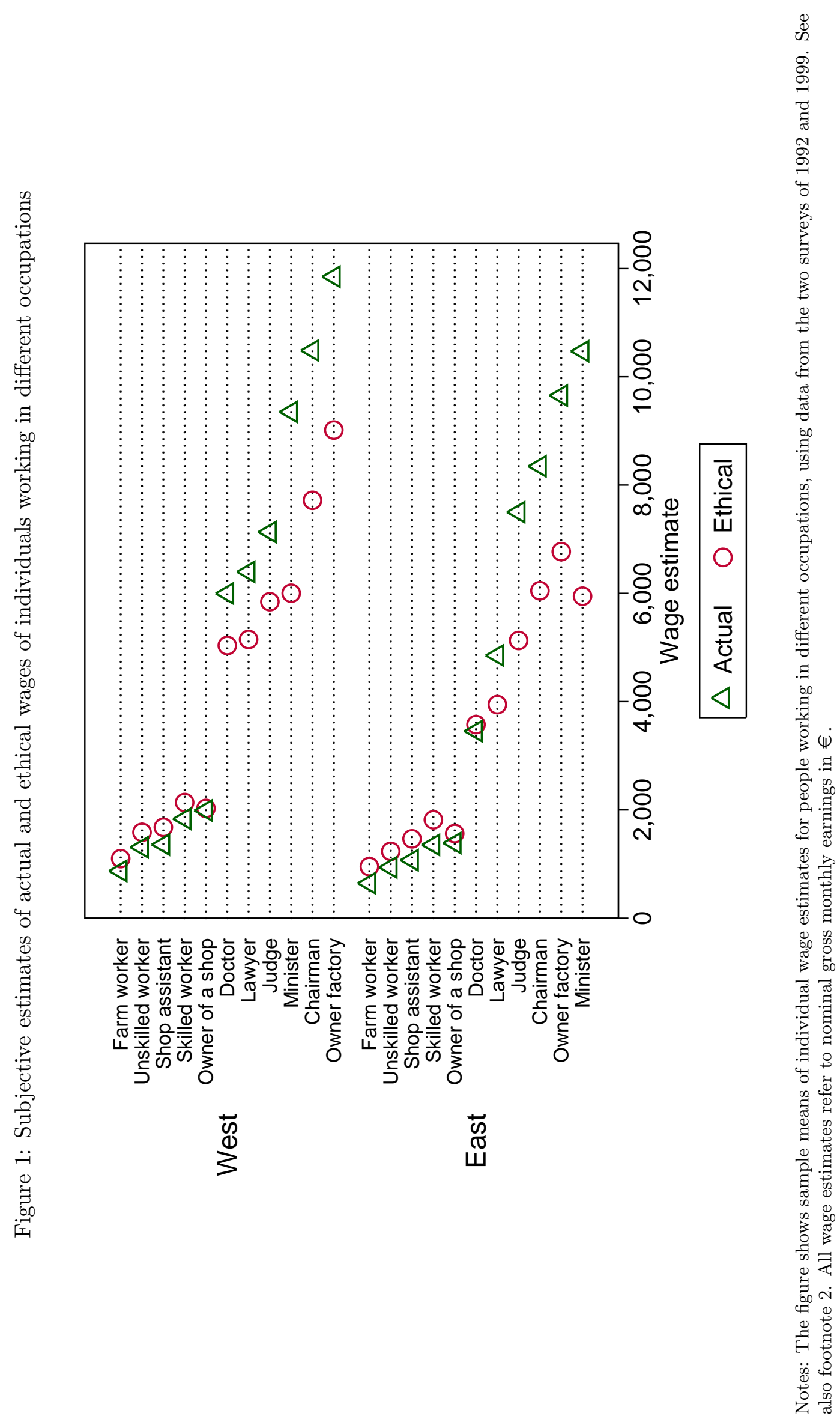



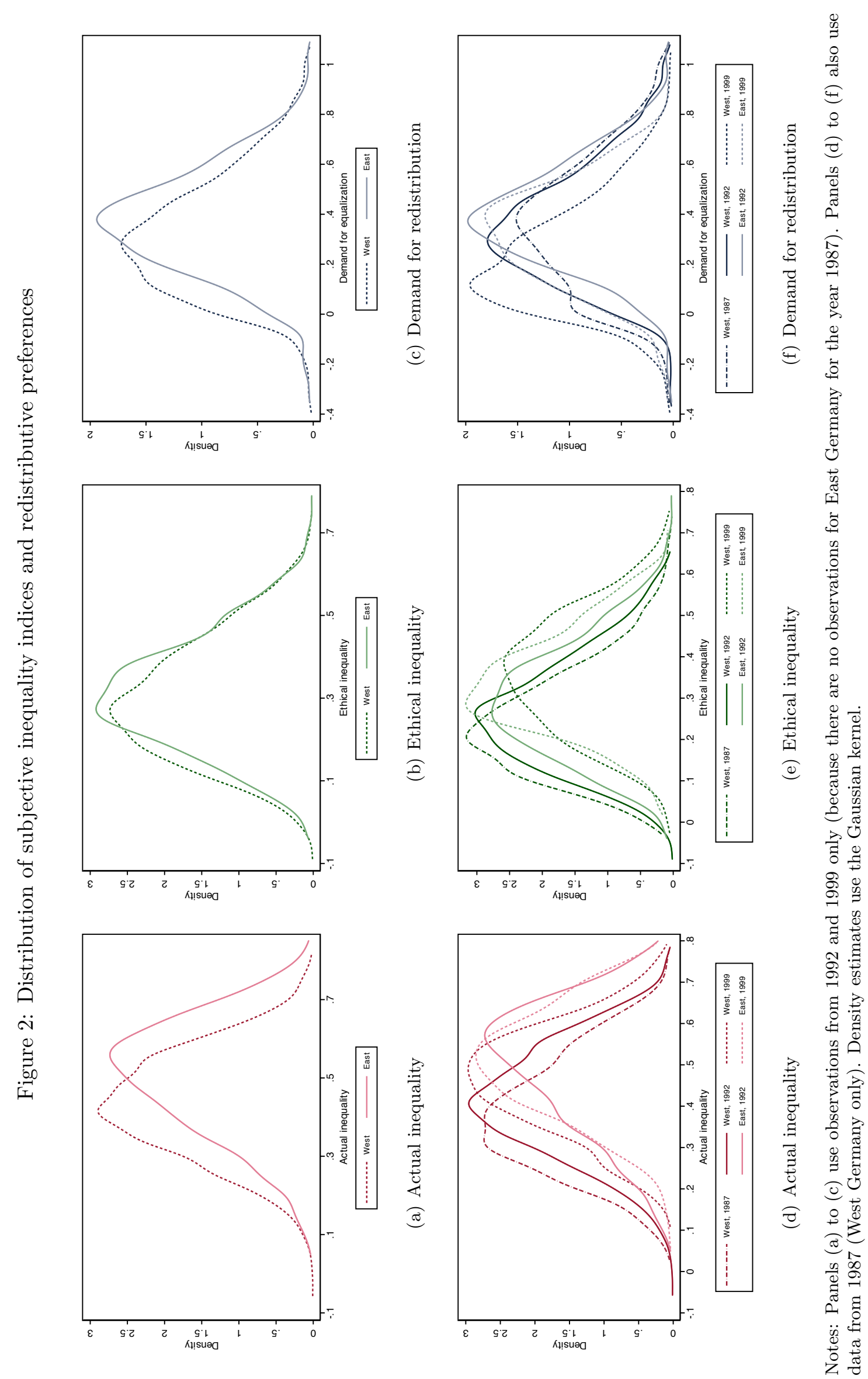


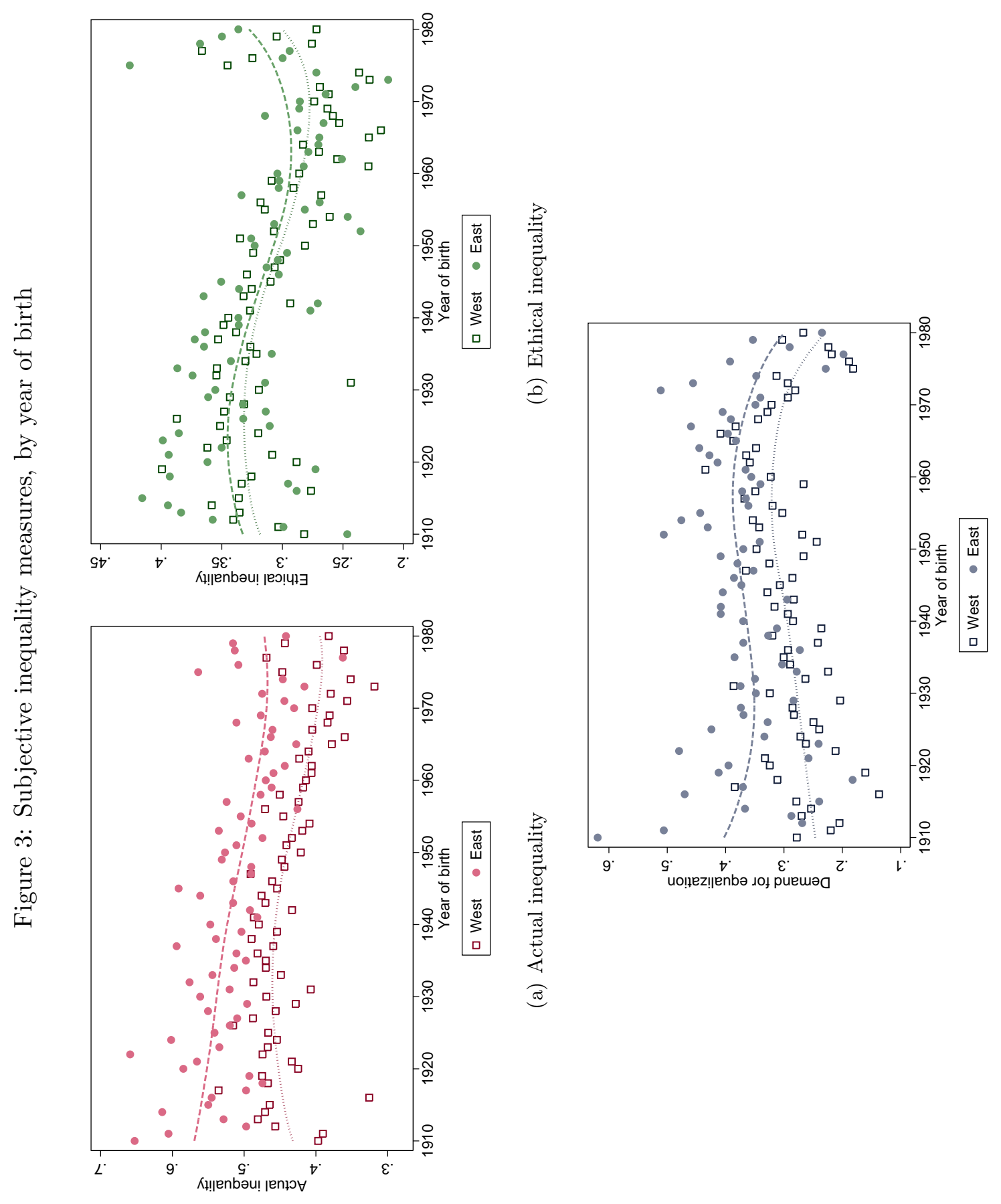




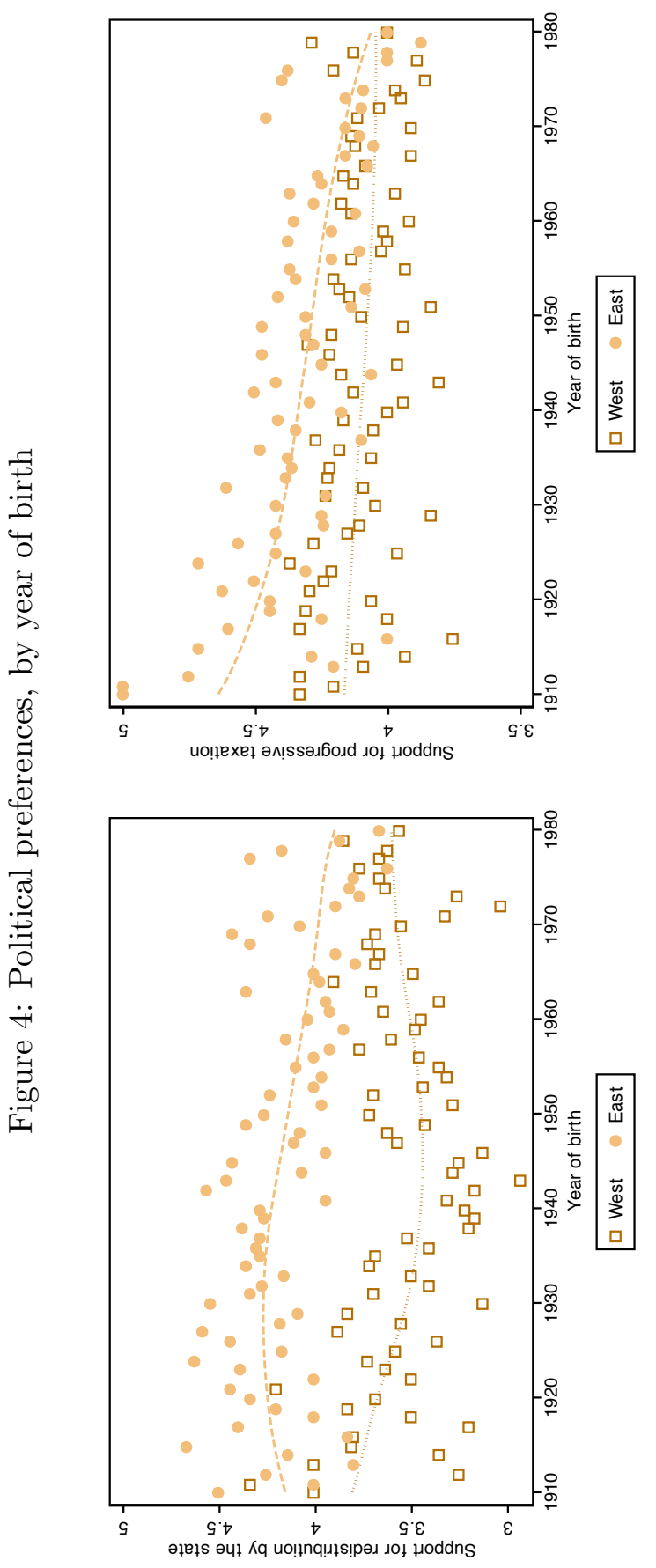

0
0
0
0
0
0
0
0
0
0
0
0
0
0
0
00
0
00
00
0
0
0
0
0
0

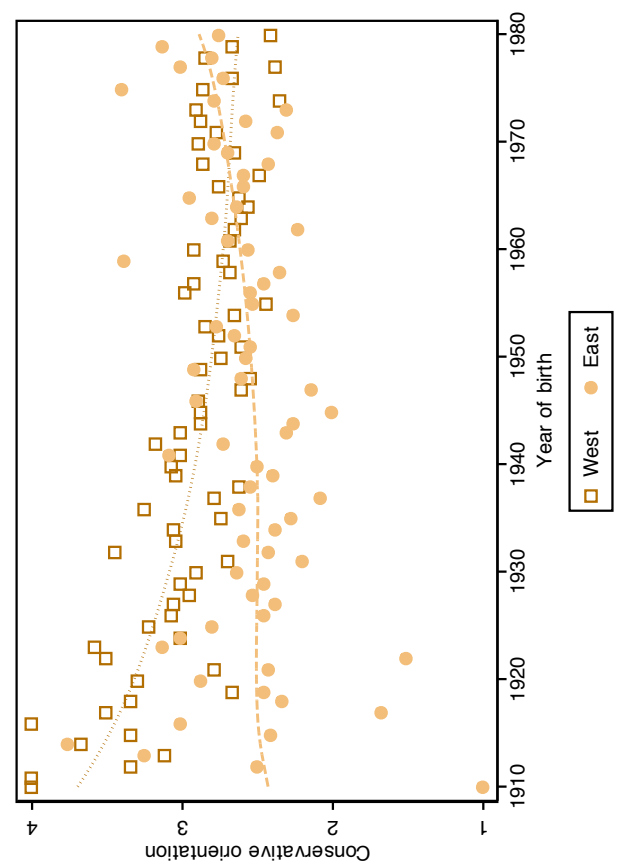

4

ह

\&

:

:

ร 


\section{A Additional Tables}

Table A.1: Descriptive statistics

\begin{tabular}{|c|c|c|c|c|c|c|}
\hline \multirow{4}{*}{$\begin{array}{l}\text { Actual inequality } \\
\mathbf{1}(\text { Actual inequality }=0) \\
\mathbf{1}(\text { Actual inequality }>0)\end{array}$} & \multicolumn{2}{|c|}{ East Germany } & \multicolumn{2}{|c|}{ West Germany } & \multicolumn{2}{|c|}{ Overall } \\
\hline & 0.502 & $(0.144)$ & 0.432 & $(0.131)$ & 0.458 & $(0.140)$ \\
\hline & 0.000 & $(0.000)$ & 0.000 & $(0.000)$ & 0.000 & $(0.000)$ \\
\hline & 1.000 & $(0.000)$ & 1.000 & $(0.000)$ & 1.000 & $(0.000)$ \\
\hline Ethical inequality & 0.312 & $(0.134)$ & 0.298 & $(0.140)$ & 0.303 & $(0.138)$ \\
\hline $\mathbf{1}($ Ethical inequality $=0)$ & 0.000 & $(0.000)$ & 0.003 & $(0.056)$ & 0.002 & $(0.045)$ \\
\hline $\mathbf{1}$ (Ethical inequality $>0$ ) & 0.995 & $(0.073)$ & 0.993 & $(0.082)$ & 0.994 & $(0.079)$ \\
\hline Demand & 0.370 & $(0.224)$ & 0.311 & $(0.243)$ & 0.333 & $(0.238)$ \\
\hline $\mathbf{1}($ Demand $<0)$ & 0.034 & $(0.181)$ & 0.055 & $(0.228)$ & 0.047 & $(0.212)$ \\
\hline $\mathbf{1}($ Demand $=0)$ & 0.014 & $(0.117)$ & 0.028 & $(0.165)$ & 0.023 & $(0.149)$ \\
\hline $\mathbf{1}($ Demand $>0)$ & 0.952 & $(0.214)$ & 0.917 & $(0.276)$ & 0.930 & $(0.255)$ \\
\hline $\mathbf{1}($ Demand $=1)$ & 0.000 & $(0.000)$ & 0.003 & $(0.056)$ & 0.002 & $(0.045)$ \\
\hline $\mathbf{1}($ Demand $>1)$ & 0.005 & $(0.073)$ & 0.003 & $(0.056)$ & 0.004 & $(0.063)$ \\
\hline Number of observations & \multicolumn{2}{|c|}{1,293} & \multicolumn{2}{|c|}{2,214} & \multicolumn{2}{|c|}{3,507} \\
\hline
\end{tabular}

Notes: All numbers refer to the pooled data from 1992 and 1999. 1(.) denotes the indicator function. All table entries are sample averages (standard deviations in parentheses). 
Table A.2: Full regression results

\begin{tabular}{|c|c|c|c|}
\hline & Actual inequality & Ethical inequality & Redistribution \\
\hline Mean & 0.439 & 0.288 & 0.338 \\
\hline Standard deviation & 0.143 & 0.138 & 0.246 \\
\hline East Germany & $\begin{array}{l}0.067^{\star \star \star} \\
(0.005)\end{array}$ & $\begin{array}{l}0.014^{\star \star \star} \\
(0.005)\end{array}$ & $\begin{array}{l}0.052^{\star \star \star} \\
(0.008)\end{array}$ \\
\hline 1992 & $\begin{array}{l}0.043^{\star \star \star} \\
(0.005)\end{array}$ & $\begin{array}{l}0.036^{\star \star \star} \\
(0.005)\end{array}$ & $\begin{array}{r}-0.008 \\
(0.010)\end{array}$ \\
\hline 1999 & $\begin{array}{l}0.067^{\star \star \star} \\
(0.006)\end{array}$ & $\begin{array}{l}0.099^{\star \star \star} \\
(0.006)\end{array}$ & $\begin{array}{l}-0.111^{\star \star \star} \\
(0.011)\end{array}$ \\
\hline Income (rank) & $\begin{array}{c}0.001 \\
(0.008)\end{array}$ & $\begin{array}{c}0.004 \\
(0.007)\end{array}$ & $\begin{array}{c}-0.001 \\
(0.015)\end{array}$ \\
\hline Social mobility & $\begin{array}{r}-0.002 \\
(0.002)\end{array}$ & $\begin{array}{c}0.004 \\
(0.002)\end{array}$ & $\begin{array}{c}-0.010^{\star \star} \\
(0.004)\end{array}$ \\
\hline $\begin{array}{l}\text { Perception that ascribed characteristics } \\
\text { are important for getting ahead }\end{array}$ & $\begin{array}{l}0.010^{\star \star \star} \\
(0.002)\end{array}$ & & $\begin{array}{r}0.008^{\star} \\
(0.004)\end{array}$ \\
\hline $\begin{array}{l}\text { Perception that acquired characteristics } \\
\text { are important for getting ahead }\end{array}$ & $\begin{array}{c}0.003 \\
(0.005)\end{array}$ & & $\begin{array}{l}-0.055^{\star \star \star} \\
(0.009)\end{array}$ \\
\hline $\begin{array}{l}\text { Belief that needs should be important } \\
\text { for getting ahead }\end{array}$ & & $\begin{array}{l}-0.012^{\star \star \star} \\
(0.003)\end{array}$ & $\begin{array}{l}0.014^{\star \star \star} \\
(0.005)\end{array}$ \\
\hline $\begin{array}{l}\text { Belief that effort should be important } \\
\text { for getting ahead }\end{array}$ & & $\begin{array}{l}0.023^{\star \star \star} \\
(0.005)\end{array}$ & $\begin{array}{l}-0.029^{\star \star \star} \\
(0.009)\end{array}$ \\
\hline Percpetion of social conflicts & $\begin{array}{l}-0.010^{\star \star \star} \\
(0.004)\end{array}$ & $\begin{array}{l}-0.026^{\star \star \star} \\
(0.003)\end{array}$ & $\begin{array}{l}0.046^{\star \star \star} \\
(0.006)\end{array}$ \\
\hline Age (years) & $\begin{array}{l}0.008^{\star \star \star} \\
(0.003)\end{array}$ & $\begin{array}{c}0.001 \\
(0.002)\end{array}$ & $\begin{array}{r}0.009^{\star} \\
(0.005)\end{array}$ \\
\hline $\operatorname{Age}^{2}$ & $\begin{array}{c}-0.001 \\
(0.001)\end{array}$ & $\begin{array}{c}0.000 \\
(0.001)\end{array}$ & $\begin{array}{l}-0.002^{\star \star} \\
(0.001)\end{array}$ \\
\hline $\mathrm{Age}^{3}$ & $\begin{array}{c}0.000 \\
(0.000)\end{array}$ & $\begin{array}{c}-0.000 \\
(0.000)\end{array}$ & $\begin{array}{l}0.000^{\star \star} \\
(0.000)\end{array}$ \\
\hline Education (years) & $\begin{array}{l}0.003^{\star \star \star} \\
(0.001)\end{array}$ & $\begin{array}{l}0.003^{\star \star \star} \\
(0.001)\end{array}$ & $\begin{array}{l}-0.004^{\star \star \star} \\
(0.001)\end{array}$ \\
\hline Female & $\begin{array}{l}-0.016^{\star \star \star} \\
(0.004)\end{array}$ & $\begin{array}{l}-0.027^{\star \star \star} \\
(0.004)\end{array}$ & $\begin{array}{l}0.039^{\star \star \star} \\
(0.008)\end{array}$ \\
\hline Unemployed & $\begin{array}{r}-0.001 \\
(0.009)\end{array}$ & $\begin{array}{c}0.006 \\
(0.008)\end{array}$ & $\begin{array}{c}-0.013 \\
(0.016)\end{array}$ \\
\hline Not in labor force & $\begin{array}{c}0.002 \\
(0.005)\end{array}$ & $\begin{array}{c}0.009^{\star} \\
(0.005)\end{array}$ & $\begin{array}{r}-0.013 \\
(0.009)\end{array}$ \\
\hline Constant & $\begin{array}{l}0.155^{\star \star \star} \\
(0.048)\end{array}$ & $\begin{array}{l}0.169^{\star \star \star} \\
(0.044)\end{array}$ & $\begin{array}{l}0.408^{\star \star \star} \\
(0.091)\end{array}$ \\
\hline $\begin{array}{l}\text { Number of observations } \\
\text { p-value (F-statistic) } \\
\text { R-Squared }\end{array}$ & $\begin{array}{r}4,660 \\
0.000 \\
0.171\end{array}$ & $\begin{array}{r}4,660 \\
0.000 \\
0.178\end{array}$ & $\begin{array}{r}4,660 \\
0.000 \\
0.101\end{array}$ \\
\hline
\end{tabular}

Notes: ${ }^{\star},{ }^{\star \star},{ }^{\star \star \star}$ denotes statistical significance on the $10 \%, 5 \%$, and $1 \%$ level, respectively. Robust standard errors are given in parentheses. All regressions also include dummies for respondents' major occupational group (10 categories). 